\title{
Wybrane możliwości technologiczne hybrydowej metody spawania Plasma-MAG
}

\author{
Selected technology abilities \\ of Plasma-MAG hybrid welding process
}

\begin{abstract}
Streszczenie
W artykule scharakteryzowano innowacyjną metodę spawania hybrydowego będącą ekonomiczną alternatywą dla spawania hybrydowego laser-MAG. Przedstawiono wybrane możliwości technologiczne oraz wybrane wyniki badań metalograficznych spoin czołowych wykonywanych metodą wysokowydajnego spawania hybrydowego PlasmaMAG. Przedstawiono korzyści techniczne i ekonomiczne wynikające z zastosowania opisanego rozwiązania.
\end{abstract}

Słowa kluczowe: spawanie hybrydowe; spoiny czołowe; metalografia

\begin{abstract}
The article describes an innovative method of hybrid welding being economical alternative to welding hybrid laser-MAG. Selected technological capabilities and selected results of metallographic butt welds made by means of highplasma hybrid welding MAG has been presented. The paper presents technical and economic benefits resulting from the use of the described solution.
\end{abstract}

Keywords: hybrid welding; butt welds; metallography

\section{Wstęp}

Spawanie hybrydowe zgodnie z definicją Międzynarodowego Instytutu Spawalnictwa polega na połączeniu i jednoczesnym stosowaniu dwóch różnych pod względem źródła ciepła metod spawania. Dodatkowym warunkiem uznania metody spawania za hybrydową jest tworzenie za pomocą kilku źródeł ciepła wspólnego jeziorka spawalniczego. Najczęściej spotykane hybrydy spawalnicze bazują na połączeniu lasera z innym spawalniczym źródłem ciepła, np.

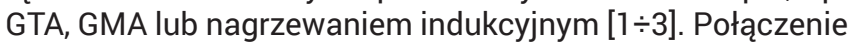
spawania plazmowego i GMA (Gas Metal Arc) z pozoru nie spełnia tego warunku, gdyż w obu przypadkach mamy do czynienia z łukiem elektrycznym. Należy jednak zwrócić uwagę, iż pomimo tego, że oba źródła ciepła bazują na łuku elektrycznym, to jednak znacznie się od siebie różnią. Sposób nagrzewania materiału rodzimego w metodach opartych na łuku "swobodnym" ma charakter przewodnościowy, a łuk plazmowy w wysokim stopniu zjonizowany o wysokiej temperaturze i gęstości mocy umożliwiającej powstanie kanału parowego (ang. keyhole) przekazuje ciepło do materiału spawanego w głównej mierze poprzez bombardowanie elektronami anody (choć mechanizm przewodnościowy również funkcjonuje), w związku z czym nagrzewanie materiału ma charakter gwałtowny i następuje w wyniku pochłaniania energii strumienia elektronów na skutek zderzeń elektronów z siecią krystaliczną materiału. Poziom energii kinetycznej elektronów, zamienianej w energię cieplną na skutek zderzenia, zależy od stopnia jonizacji i wartości napięcia przyśpieszającego. Dwa z pozoru podobne źródła energii spawania $\mathrm{w}$ różny sposób przekazują ciepło do materiału obrabianego. Spawanie plazmowe w technice kanału parowego (keyhole PAW) ma istotną przewagę wobec metod spawania łukowego (np. GTA, czy GMA) pod względem głębokości „wtopienia”, poziomu i stanu naprężeń własnych w złączu [4]. Pomimo, iż gęstość mocy w porównaniu do spawania laserowego (LBW) i wiązką elektronów (EBW) jest niższa, to spawanie plazmowego w technice kanału parowego jest bardziej ekonomiczne pod względem energetycznym (wyższa sprawność źródła energii) oraz z punktu widzenia kosztów przygotowania brzegów do spawania, z tego powodu często znajduje zastosowanie w przemyśle.

\section{Spawanie hybrydowe Plasma+MAG}

Uwarunkowania ekonomiczne rynku spawalniczego stymulują poszukiwanie nowych wysokowydajnych oraz charakteryzujących się wysoką jakością metod spawania przy jednocześnie spełnionym warunku umiarkowanych kosztów procesu. Konwencjonalne metody spawalnicze przy swej dużej różnorodności, niestety nie są doskonałe, a ich indywidualne charakterystyczne cechy predysponują do określonych zastosowań. Jeśli określona metoda spawania wyróżnia się jakąś specyficzną zaletą, to zwykle jest to okupione równie ważnym mankamentem. Przykładem może być wysoka

Mgr inż. Jacek Szulc - SupraElco Warszawa; dr hab. inż. Tomasz Chmielewski, prof. PW.; dr inż. Marek Węglowski - Akademia Spawania, Józefów.

Autor korespondencyjny/Corresponding author. t.chmielewski@wip.pw.edu.pl 
jakość spoin wykonanych metodą TIG przy niskiej wydajności spawania (stapiania), bądź wysoka wydajność metod opartych na wiązkach energetycznych, kojarząca się niestety z wysokimi kosztami przygotowania brzegów do spawania oraz niską sprawnością energetyczną źródła (np. laser).

W spawalniczych systemach hybrydowych z reguły stosuje się metody o skrajnie różnych właściwościach. Takie podejście umożliwia uzyskanie wysokiej wydajności procesu spajania poprzez jednoczesne wykorzystanie i wzmocnienie zalet obu łączonych metod oraz minimalizowanie ograniczeń charakterystycznych dla zastosowanych metod, wtedy gdy występują osobno. Łuk plazmowy umożliwia precyzyjne przetopienie grani spoiny spoin o dużej grubości, której jakość decyduje o jakości całej spoiny, a metoda MAG umożliwia wydajne wypełnienie rowka spawalniczego i uformowanie wypukłego lica. Połączenie obu głowic w hybrydę umożliwia wspólne prowadzenie, lepsze wykorzystanie ciepła generowanego przez oba źródła, a także wspólną osłonę gazową strefy spawania i hybrydowej głowicy.

Obecnie w hybrydowych systemach spawalniczych najczęstsze zastosowanie znajduje LASER współpracujący z łukowymi metodami spawania w osłonie gazów, najczęściej MAG, MIG, TIG. Korzyści ze stosowania hybrydy laser-GMA polegają na połączeniu charakterystycznych dla lasera, wysokiej wydajności stapiania, dużej głębokości wtopienia oraz niskiego udziału spoiwa w stopiwie, ze stosunkowo wysoką tolerancją na jakość przygotowanych do spawania brzegów charakterystyczną dla metod łukowych. Poza szeregiem zalet opisanej hybrydy trudno pominąć bardzo wysokie koszty inwestycyjne i eksploatacyjne systemów laserowych oraz stosunkowo niską sprawność energetyczną, które w pewnym stopniu niwelują ekonomicz-



Generalnie, metody spawania hybrydowego umożliwiają wykonanie połączenia z łagodnym cyklem cieplnym (spoina stosunkowo wolno stygnie) i zmniejszają wymagania wobec przygotowania szczeliny rowka spawalniczego w stosunku do metod wiązkowych. Metody spawania hybrydowego charakteryzuje wysoka prędkość spawania w stosunku do indywidualnych możliwości poszczególnych metod spawania

Niskotemperaturowa plazma znajduje częste zastosowanie w napawaniu modyfikacyjnym i regeneracyjnym powierzch-

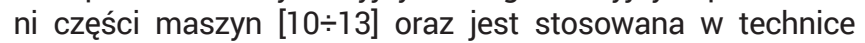
$z$ otwartym kanałem parowym do spawania grubych elementów konstrukcyjnych. Spawanie plazmowe kojarzy się z wysoką wydajnością spawania, jednak wymaga precyzyjnego i kosztownego przygotowania brzegów, a wymaganie to w warunkach przemysłowych jest często niewykonalne, zwłaszcza podczas spawania konstrukcji wielkogabarytowych. Sposobem na rozwiązanie problemów ze stosowaniem w przemyśle spawania plazmowego w kontekście tolerancji geometrycznej brzegów przygotowanych do spawania, może być spawanie hybrydowe Plasma-GMA. Połączenie zalet obu metod prowadzi do uzyskania wysokiej wydajności spawania przy obniżeniu (w stosunku do metod wiązkowych) wymagań związanych z precyzyjnym przygotowaniem brzegów.

Prezentowany hybrydowy system spawania Plasma-MAG został opisany w literaturze $[5,6,7,8]$ oparty jest na specjalnej konstrukcji plazmotronie zintegrowanym z uchwytem elektrodowym GMA, będącym przedmiotem patentu firmy Plasma Laser Technologies z Izraela. Innowacyjność rozwiązania konstrukcyjnego polega na tym, że łuk plazmowy oraz łuk GMA oddzielone są od siebie kurtyną magnetyczną wymuszającą przepływ prądu łuku plazmowego i GMA przez materiał spawany. W innym przypadku, następowałoby wzajemne znoszenie strumieni elektronów ze względu na przeciwną polaryzację. Na rysunku 1 pokazano schemat budowy plazmotronu hybrydowego szerzej opisanego w [8].

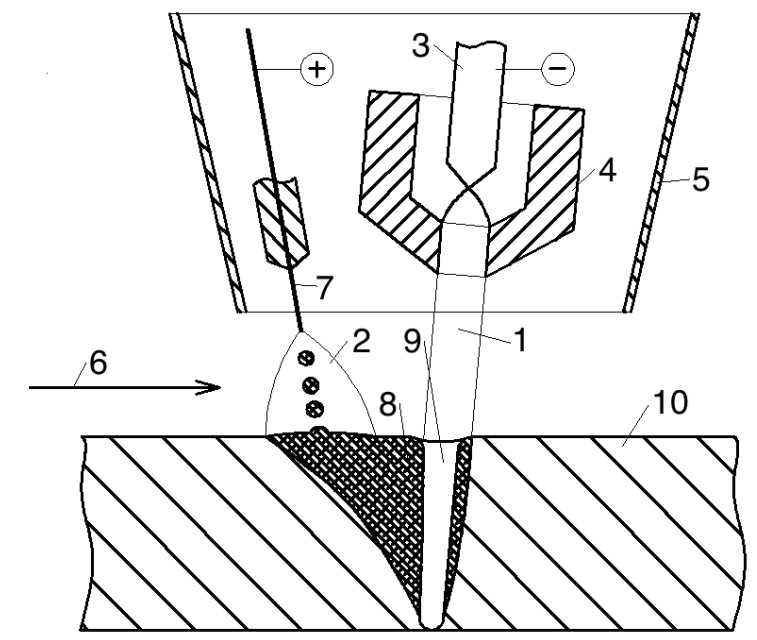

Rys. 1. Schemat budowy plazmotronu hybrydowego: 1-łuk plazmowy, 2-łuk GMA, 3-katoda plazmotronu, 4-dysza plazmowa, 5-wspólna dysza gazu osłonowego, 6-kierunek spawania, 7-drut elektrodowy GMA, 8-ciecz metaliczna, 9-kanał parowy, 10-materiał podstawowy Fig. 1. Schematic diagram of the hybrid plasmatron: 1-plasma arc, 2-GMA arc, 3- plasmatron cathode, 4-plasma nozzle, 5- common shielding gas nozzle, 6-welding direction, 7-GMA wire electrode, 8- liquid metal, 9-plasma keyhole, 10-substrate material

Łuk plazmowy zasilany jest prądem o natężeniu umożliwiającym wywołanie efektu kanału parowego (ang. Keyhole welding), będącego wynikiem wysokiej temperatury i ciśnienia strumienia plazmy, powodującej gwałtowne parowanie spawanego materiału. Parametry procesu dobierane są tak, by głębokość kanału parowego była porównywalna z grubością spawanego elementu, a jego szerokość sięgała obu brzegów spawanych materiałów. W ten sposób uzyskiwane jest bardzo głębokie wtopienie spoiny. W efekcie intensywnego parowania metalu oraz minimalnego, ale jednak odstępu brzegów spawanych przedmiotów, lico spoiny powstającej za przemieszczającym się łukiem plazmowym byłoby wklęsłe, gdyż do jego wypełnienia brakowałoby masy stopiwa. Wraz z tukiem plazmowym przemieszcza się łuk GMA swobodnie jarzący się w przestrzeni pomiędzy elektrodami, zasilający jeziorko w spoiwo $[14,15]$. Łuk GMA oddziałuje na jeziorko spawalnicze tuż za łukiem plazmowym, jeszcze przed skrystalizowaniem cieczy powstałej na skutek działania plazmy. Okno technologiczne opisanej hybrydy jest bardzo wąskie i dla utrzymania stabilności procesu, wymaga wysokiej precyzji ruchu roboczego.

\section{Przykłady wybranych złączy spawanych}

Poniżej scharakteryzowano kilka przykładowych złączy spawanych wykonanych metodą hybrydową Plasma-MAG. W pierwszym przypadku materiał podstawowy to stal niestopowa S235 JR o grubości 10 i $12 \mathrm{~mm}$. Spawanie prowadzono w sposób zrobotyzowany w pozycji podolnej bez podgrzewania. Zgład preparowano przez szlifowanie papierem ściernym o gradacji od 100 do 2500, następnie polerowano wodną zawiesiną $\mathrm{Al}_{2} \mathrm{O}_{3}$, po czym trawiono $30 \%$ nitalem. Mikrostrukturę badanego złącza fotografowano na mikroskopie stereoskopowym Olympus stosując powiększenie x6. Pomiary charakterystycznych wielkości geometrycznych wykonano stosując oprogramowanie Olympus Analysis.

Na rysunku 2 przedstawiono obraz mikrostruktury złącza teowego - spoina czołowa (linie punktów od strony lica oznaczają miejsca pomiaru twardości), a na rysunku 3 rozkład twardości złącza wykonanego w poniżej przedstawionych warunkach. Grubość blach $10 \mathrm{~mm}+10 \mathrm{~mm}$; bez ukosowania, odstęp 1,5 mm; natężenia prądu spawania 
- plazma - 200 A; MAG 540 A; napięcie tuku MAG - 30 V; prędkość spawania - 0,52 $\mathrm{m} / \mathrm{min}$; posuw drutu elektrodowego $-12 \mathrm{~m} / \mathrm{min}$. Odnotowano wąską strefę wpływu ciepła, o szerokości około $2 \mathrm{~mm}$. Taka sytuacja jest bardzo korzystna z punktu widzenia poziomu naprężeń własnych złącza oraz odkształceń cieplnych. Przedstawiony poniżej rozkład twardości wskazuje, że nie występuje nadmierne utwardzenie SWC, mimo iż nie stosowano podgrzewania wstępnego.

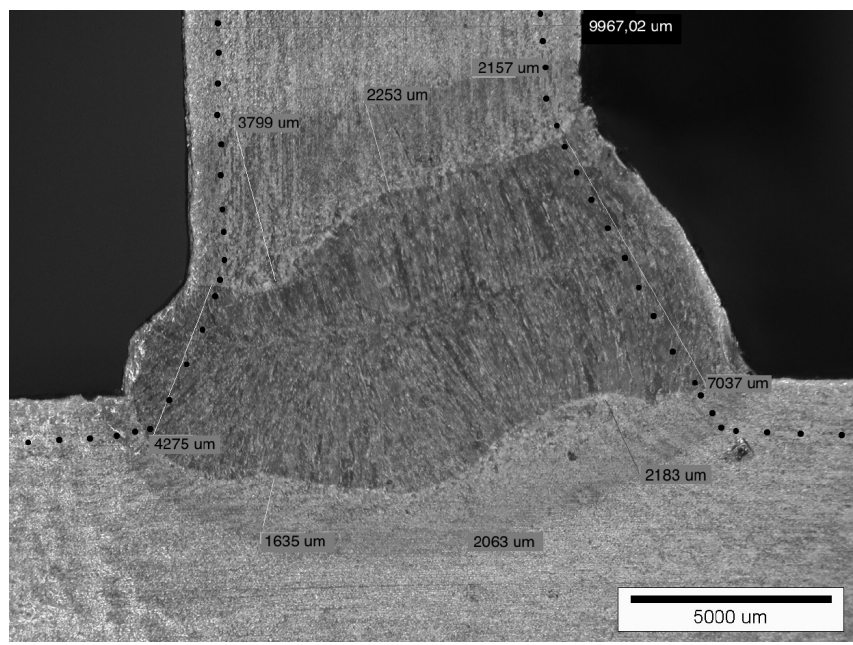

Rys. 2. Rozkład twardości w spoinie czołowej $10 \mathrm{~mm}$ od strony lica Fig. 2. Hardness distribution in butt-weld $10 \mathrm{~mm}$ - bead side

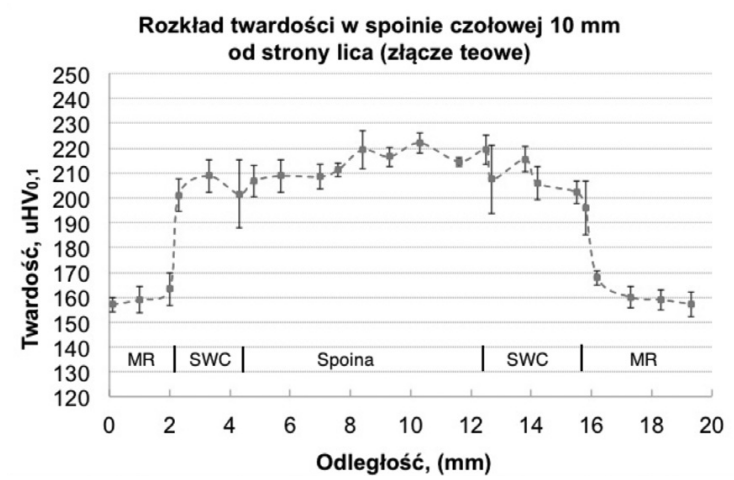

Rys. 3. Rozkład twardości w spoinie czołowej $10 \mathrm{~mm}$ od strony lica Fig. 3. Hardness distribution in butt-weld $10 \mathrm{~mm}$ - bead side

Drugi przykład złącza spawanego dotyczy złączy doczołowych, blach o grubości $10 \mathrm{~mm}$ ze stali S700 MC spawanych hybrydowo (Plasma-MAG) na podkładce miedzianej w pozycji PA. Na rysunku 4 pokazano obraz mikrostruktury złącza.

Badania mikroskopowe w obszarze spoiny ujawniły strukturę bainityczno-ferrytyczną. Obszar strefy wpływu ciepła (SWC) charakteryzuje się zmiennością wielkości ziarna, potwierdzając m.in. dużą skłonność do rekrystalizacji w SWC. Badania mikroskopowe wykazały również obecność wydzieleni węglikowych (najprawdopodobniej azotkowych) w obszarze SWC oraz w materiale rodzimym.

Przeprowadzone pomiary twardości, wykazały że twardość w osi spoiny jest zbliżona do twardości materiału rodzimego i wynosi około $280 \mathrm{HV}_{0,1}$. W SWC dochodzi do obniżenia twardości zależnie od zastosowanej wartości energii liniowej spawania. W próbkach spawanych z energią liniową spawania $E_{l}=1,12 \mathrm{KJ} / \mathrm{mm}$, najniższa wartość twardości w SWC wynosi około $230 \mathrm{HV}_{0,1}$.

Rozkłady twardości w przekroju poprzecznym spoiny wykonano od strony lica metodą mikro Vickersa z obciążeniem wgłębnika masą 100 gr. Na wykresie (rys. 5.) przedstawiono średnią arytmetyczną twardość obszaru charakterystycznego z zaznaczeniem wartości odchylenia standardowego (przyjęty poziom ufności 95\%).

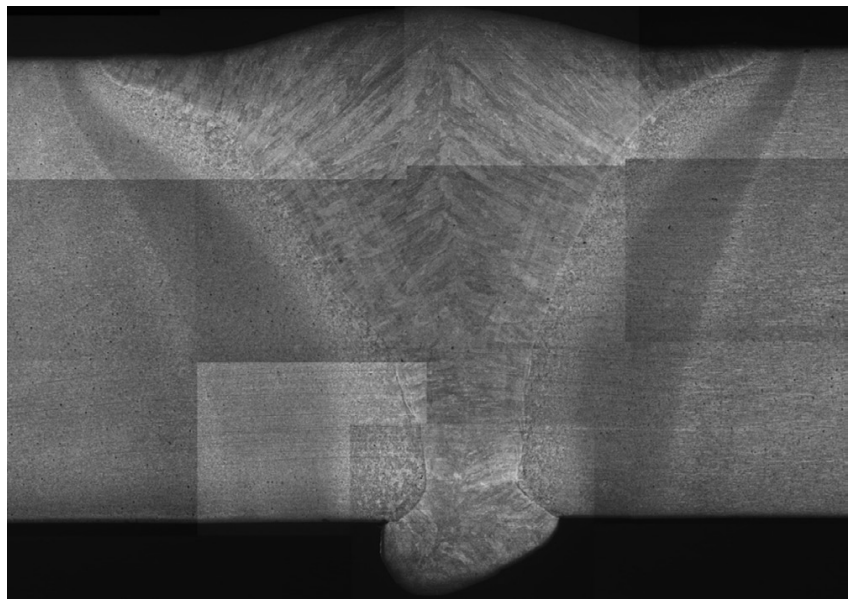

Rys. 4. Mikrostruktura złącza spawanego metodą hybrydową (plazma + MAG) stali S700 MC o grubości $10 \mathrm{~mm}$, wykonanej z energią liniową spawania $1,12 \mathrm{KJ} / \mathrm{mm}$

Fig. 4. Microstructure of S700 MC steel welded joint obtained by hybrid plasma+MAG welding, thickness $10 \mathrm{~mm}$, heat input $1,12 \mathrm{KJ} / \mathrm{mm}$

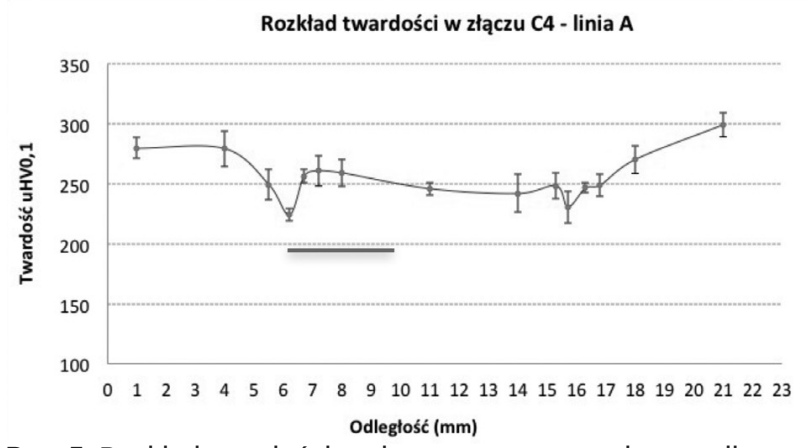

Rys. 5. Rozkład twardości w złączu spawanym od strony lica wykonanym z energią liniową spawania $\mathrm{E}_{\mathrm{l}}=1,12 \mathrm{KJ} / \mathrm{mm}$

Fig. 5. Hardness distribution in the welded joint bead side with heat input $\mathrm{E}_{1}=1,12 \mathrm{KJ} / \mathrm{mm}$

Trzeci przykład złącza potwierdza możliwość spawania złączy doczołowych metodą hybrydową Plasma-MAG w pozycji naściennej PC [16]. Jako materiał podstawowy zastosowano stal nierdzewną X5CrNi18-10 o grubości 10 $\mathrm{mm}$. Złącze do spawania przygotowano ukosując na $15^{\circ}$ jednostronnie (na $1 / 2 \mathrm{Y}$ ), z progiem wysokości $4 \mathrm{~mm}$, odstęp $1 \mathrm{~mm}$. Parametry spawania: natężenie prądu plazmy $170 \mathrm{~A}$, napięcie łuku plazmy 23 V, natężenie prądu MAG Puls 273 A, napięcie łuku MAG $22 \mathrm{~V}$, prędkość spawania 0,6 m/min, gaz formujący $\mathrm{N}_{2}+10 \% \mathrm{H}_{2}$. Na rysunku 6 pokazano mikrostrukturę złącza charakteryzującą się nieznaczną asymetrią wynikającą z asymetrycznego przygotowania brzegów do spawania oraz z oddziaływania grawitacji na ciecz metaliczną podczas spawania.

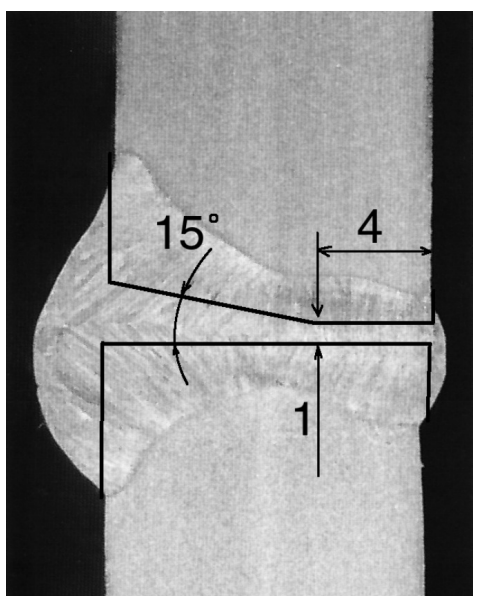

Rys. 6. Mikrostruktura złącza stali X5CrNi18-10 gr. 10 $\mathrm{mm}$ spawanego hybrydowo Plasma+MAG w pozycji PC ukosowanego jednostronnie Fig. 6. Microstrukture of single-bevel butt $10 \mathrm{~mm} \times 5 \mathrm{Cr}$ Ni18-10 steel joint, welded with Plasma+MAG in $\mathrm{PC}$ position 


\section{Podsumowanie}

W artykule przedstawiono przykłady spawania hybrydowego Plasma-GMA różnych złączy spawanych, które wskazują na możliwość spawania grubych elementów spoinami jednościegowymi przy ograniczonej konieczności ukosowania, do gr. blach $10 \mathrm{~mm}$ ukosowano na $15^{\circ}$ jedno i dwustronnie. Charakterystyczną cechą opisanych spoin jest niski udział spoiwa w stopiwie oraz bardzo wąska SWC, uwzględniając grubość spawanych blach. Takie warunki ograniczają poziom naprężeń własnych w stosunku do podobnych złączy wykonywanych metodami GMA lub GTA. Dużą zaletą jest stosunkowo wysoka prędkość spawania oraz wysoka wydajność stapiania. Opisana metoda może stanowić tańszą alternatywę dla hybrydowych systemów spawalniczych Laser+GMA. Głównymi obszarami potencjalnego zastosowania spawania hybrydowego Plazma+GMA są: przemysł stoczniowy, przemysł maszyn i urządzeń górniczych, konstrukcje w dziedzinie energetyki, tabor kolejowy oraz duże konstrukcje motoryzacyjne.

\section{Literatura}

[1] T. Wojno, J. Kędzia, Z. Mirski, J. Reiner, „Hybrydowe spawanie stali 41 Cr4 z wykorzystaniem promieniowania laserowego i nagrzewania indukcyjnego", Przegląd Spawalnictwa, vol. 85 (7), s.40-47, 2013.

[2] J. Adamiec, P. Adamiec, M. Więcek, „Spawanie hybrydowe paneli ścian szczelnych za pomocą lasera światłowodowego", Przegląd Spawalnictwa, vol. 79(10) s. 49-52, 2007.

[3] J. Pilarczyk, M. Banasik, J. Dworak, S. Stano, „Spawanie hybrydowe z wykorzystaniem wiązki laserowej i łuku elektrycznego", Przegląd Spawalnictwa, vol. 79(10), s. 44-48, 2007.

[4] M. Tomsic, S. Barhorst, „Key-hole plasma arc welding of aluminum with variable polarity power" Welding Journal 63(2): s. 25-32, 1984.

[5] Z. Pilat, J. Szulc, "Concept of the Model Robotized Cell for Plasma-GMAW Hybrid Welding", Applied Mechanics and Materials, Vol. 613, pp. 43-52, 2014.

[6] J. Szulc, Z. Pilat, „Super-Heavy Duty (SHD) Super-MIG - Technologia spawania hybrydowego Plazma-MIG/MAG", Spajanie materiałów konstrukcyjnych, 2/2014, s.12-14. 2014.

[7] T. Chmielewski, J. Szulc, Z. Pilat, „Badania metalograficzne spoin wykonanych hybrydową metodą PTA+MAG", Przegląd Spawalnictwa, Vol. 86(7), s. 46-50, 2014.

[8] J. Szulc, T. Chmielewski, Z. Pilat, „Zrobotyzowane spawanie hybrydowe Plazma+MAG stali S700 MC", Przegląd Spawalnictwa, vol. 88(1), s. 41-45, 2016.

[9] T.Wojno, J. Kędzia, Z. Mirski, J. Reiner, „Hybrydowe spawanie stali 41 Cr4 z wykorzystaniem promieniowania laserowego i nagrzewania indukcyjnego", Przegląd Spawalnictwa, vol. 85(7) s. 40-47, 2013.
[10] J. Jakubowski, P. Wysocki, J. Senkara, „Selektywne regeneracyjne napawanie plazmowe warstw Ni-WC na tytanowe łopatki sprężarki silnika lotniczego", Przegląd Spawalnictwa, vol. 83(9), s. 38-42, 2011.

[11] M. Bober, J. Senkara, „Badania porównawcze napawanych plazmowowarstw niklowych z węglikami Ti i Cr", Przegląd Spawalnictwa, vol. 83(9), s. 32-37, 2011.

[12] W. Włosiński, T. Chmielewski, „Plasma-hardfaced chromium protective coatings-effect of ceramic reinforcement on their wettability by glass", Contributions of Surface Engineering to Modern Manufacturing and Remanufacturing 1, s.48-53, 2002.

[13] T. Chmielewski, M. Węglowski „Analiza rynku spawalniczego w Polsce pod względem sprzedaży urządzeń oraz materiałów spawalniczych", Przegląd Spawalnictwa, Vol. 82(6), 28-31, 2010.

[14] M. Węglowski, T. Chmielewski, K. Kudła, „Porównanie wybranych właściwości nowoczesnych spawalniczych inwertorowych źródeł energii przeznaczonych do spawania metodą MAG", Przegląd Spawalnictwa, Vol. 81(10), s. 81-83, 2009.

[15] T. Chmielewski, „Projektowanie procesów technologicznych - Spawalnictwo", Oficyna Wydawnicza Politechniki Warszawskiej, 2013.

[16] M. Huber, M. Muller, H. Cramer, "Serial coupling of the plasma and GMA process in order to increase the economic viability and process reliacility of welding in installation engineering and tank construction", Welding and Cutting, vol. 14 (3), s. 168-172, 2015. 